\title{
Law and Social Theory: Three Problems
}

\author{
Gunther TEUBNER* \\ Goethe-University Frankfurt am Main
}

\begin{abstract}
This paper explores the relationship between law and social theory through a discussion of the shifting views over the last century. The conversation is framed by the example of publication bias in private-public partnership networks, and the inability of a single social theory, including theories of morality and economic utility, to explain the situation's complexities. The paper argues that where social theory meets law an added value can be generated in terms of legal doctrine if the precarious relationship between autonomy and interconnectedness is respected in terms of transversality, responsiveness, and self-normativity.
\end{abstract}

Keywords: law and social theory, publication bias, transversality, responsiveness, selfnormativity

\section{INTRODUCTION}

This is a subject that has occupied me since I wrote my doctoral thesis, i.e. for the past 40 years. I would like to summarize my experience of the relationship between law and social theory:

1. There is no single social theory upon which the law could orient itself. Such a theory cannot exist, neither ought it to exist.

2. Over the last 80 years, German law has on three occasions succumbed to the temptation to subject itself totally to a theory of society. This has led to two theory disasters. It remains to be seen whether the third such disaster will also occur in the law.

3. The law is faced with a dilemma here. Total acceptance of a social theory is impossible, yet of necessity the law is exposed to the influence of social theory. The way out could be: a "distanced approach," whereby the law does not take social theories at their nominal value, but in a complex process of translation generates "added value" to legal doctrine.

Verba docent, exempla trahunt. So let me begin with a legal case. 


\section{PUBLICATION BIAS: A LEGAL CASE AND THREE THESES}

Publication bias - this is a worrying but widespread phenomenon that is being discussed in a number of countries. ${ }^{1}$ In order to develop an effective drug against a serious but rare disease, various private and public institutions join together to form a private-public partnership (PPP) network, based on bilateral agreements among them. Since the high costs make such projects unprofitable for the pharmaceutical industry, the financing is mainly provided by a private foundation and subsidies are paid by the national health department. A university institution undertakes the basic research, while the clinical studies are carried out by a private research institution, a contractual research organization. A private pharmaceutical company organizes the production and marketing of the drug. A communication agency takes care of the dissemination of information and publication of results in scientific publications and the media.

Following successful licensing on the basis of the clinical studies presented, the drug comes on to the market. However, after a while reports begin to mount up on serious side effects in many patients. Subsequent systematic research shows that the PPP network has been responsible for serious manipulation. The side effects were well known within the network, but the network has successfully prevented publication of the relevant results. The publication of experiments in which negative consequences occurred has been suppressed. ${ }^{2}$ This had been indeed authorized by the bilateral agreements between the research institutions and the pharmaceutical company. ${ }^{3}$ Other series of experiments have been published, but their results have been falsified in favour of positive effects. ${ }^{4}$ It was not just the pharmaceutical company that was involved in the manipulation, but also the groups of researchers and the communication agency, which had their own interest in providing a falsified presentation of the results.

The numerous scandals surrounding publication bias have certainly given rise to strong reactions. Empirical studies have shown that this is a ubiquitous problem. Initial attempts are also being made to take regulatory counter-measures. Yet the problems that arise here are not simply problems of political control, but also fundamental issues relating to constitutional law: Does the fundamental right of academic freedom also give rise to third-party effects within semi-private PPP networks? Can the fundamental right of patients to health be asserted vis-à-vis the network or individual members of the network?

The question of whether and how fundamental rights can claim validity vis-à-vis private networks is also of great interest as far as social theory is concerned. Theories of the

1. Cf. Song \& Loke (2013); Song \& Hooper (2010); Schott (2010), pp. 279-85; Teil 2 (2010), pp. 295-301.

2. An example: at the end of the 1980s the pharmaceutical group Sandoz commissioned a working group at the University of Tennessee at Memphis to carry out the MIDAS study, which was supposed to compare a new calcium channel blocker with older and cheaper drugs. When the results revealed that the new drug offered no benefits compared with tried and tested ingredients, and in fact indicated many harmful side effects, Sandoz tried to prevent the publication of the study data by putting pressure on the research team; cf. Applegate et al. (1996), pp. 297-8.

3. A researcher at the University of California received a research grant from Boots Pharmaceuticals and undertook not to make any potential negative results public without the agreement of the Group. On the basis of the contractual censorship clause, publication was prevented over a period of years. A legal action was brought against the Group for suppression of data, dishonest advertising, and violation of consumer regulations; cf. King (1996), pp. 1, 6 .

4. In 1997, Pfizer published only a small part of the studies actually carried out on its antidepressant drug, specifically only the positive results, while data concerning potential side effects and the efficacy of the ingredient were withheld; cf. Eyding (2010), p. 341. 
"network society," as developed by Manuel Castells for example, see the collective actor networks throughout society as the distinguishing characteristic of post-modern societies, and identify "network failures" as serious social risks. ${ }^{5}$ The way fundamental rights are being endangered in non-governmental spheres, in markets, organizations, and networks, is not only a matter of concern to jurists, but is also an issue raised by various social theories, for example the constitutional sociology of Chris Thornhill; it is a phenomenon which is attributed to the expansionary tendencies of non-governmental collective actors. ${ }^{6}$

Since both of these subject areas are juristic "virgin territory," the findings of social theory may well prove to be highly relevant for the law. However, if we are seeking specific conclusions as far as legal practice is concerned, we are faced with some thorny problems:

1. Competition between theories: How is the law supposed to make a selection if competing social theories give rise to mutually incompatible analyses of networks, or simply do not agree concerning the validity and effect of fundamental rights vis-à-vis non-governmental collective actors? On this point, my thesis in a single word is: transversality.

2. Knowledge transfer: Can the results of social theories be directly applied within the law, i.e. can they be implemented in network adequate standards of fundamental rights? And can social theories guide the selection of sanctions against violations of fundamental rights so that they can be effective vis-à-vis the particular logic of networks? Again, my thesis can be expressed in a single word: responsiveness.

3. Finally, there is the extremely difficult question of the normativity of social theories: Can normative criteria for fundamental rights in mixed public-private networks be derived from social theories? My thesis: self-normativity.

\section{THESIS 1: TRANSVERSALITY}

\subsection{The Particularities of German History}

In Germany, the relationship between social theory and law has experienced highs and lows which have not arisen to such an extreme extent elsewhere. It started at a general European level, with periods in which jurisprudence existed in a close symbiotic relationship with theories about how humans live together. This applies not only to cosmologies of natural law, but also to the period of the Enlightenment, when philosophy boldly claimed to develop a social theory which would lay down binding principles in regard to politics and law. The law of reason expressed this symbiotic relationship, in which, according to Franz Wieacker, "the old western philosophy of law and society ('natural law'), in the form which had been given to it by the early Enlightenment, acquired direct influence on jurisprudence, legislation and the administration of justice among most European nations."7 This development reached its high point in the German-speaking countries, when Carl von Savigny responded to the social theory of Immanuel Kant, formulated as a society of individuals, with the modern-day

\footnotetext{
5. Castells (2000); Weyer (2011).

6. Thornhill (2013).

7. Wieacker (1967), p. 249.
} 
Roman Law system: "All law exists because of the moral freedom inherent in each individual human being." choice which are ideally delimited from each other in such a way that the law can assume a form which is capable of generalization, was translated into a legal doctrine which saw itself as a comprehensive system of subjective rights.

Soon, however, philosophy had to give up its role as the "leading science" for the law. Due to the advancing functional differentiation of society, different spheres of rationality within society each took on their own separate existence, so that it was no longer possible to hold on to a single overriding viewpoint from which a unified legal concept of society could be developed. ${ }^{9}$ In today's "society without any apex or centre," as Niklas Luhmann describes it, ${ }^{10}$ it is in principle impossible to devise any generally valid social theory into which the law could be incorporated. "Under these conditions the social system itself becomes so complex that it is no longer possible to make do with a single system description." ${ }^{11}$ Instead, from a perspective of social rationalities that are utterly different, and yet are interwoven with and dependent upon each other, a multiplicity of independent social theories are developed. This situation does not even give rise to a "normal" controversy of theories that could ultimately be decided in favour of whichever theory is the most plausible. On the contrary, an entirely new kind of situation arises, to which the philosopher Günther Gotthard has given the name "polycontexturality."12 Out of their own specific rationality, different social "meaning worlds" create their own separate theories of society, which generally speaking can no longer be reduced to a single standard theory, but exist side by side on a basis of equal origin. Max Weber has already spoken of a "new polytheism" in a historical situation, which makes any "monotheism" of theories impossible. ${ }^{13}$ There is no longer one theory of society, but only equally justified partial theories relating to areas of society. Yet each one of these-and this is what gives rise to concern - at the same time lays claim to universal validity as the only valid theory of society. It is this paradox - a multiplicity of partial rationalities with totalitarian claims - that the law has to face today, if it aims to find a satisfactory relation to social theory. ${ }^{14}$

Economic theories have long since gone beyond the boundaries of their actual subject area-economics - and claim to provide a theory of all social relationships, which society, and therefore also the law, understands as a vast network of utility calculations. Efficiency becomes a principle of law. ${ }^{15}$ In a similar way, political theories perceive society as power and interest conflicts between groups and political assemblies, and claim to represent a binding "leading science" in regard to society and the law. ${ }^{16}$ The democratic-consensual

\footnotetext{
8. Carl von Savigny (1840), p. 2.

9. The most important sociological contribution to social theory is probably theories of social differentiation as developed by Emile Durkheim, Georg Simmel, Max Weber, Talcott Parsons, Pierre Bourdieu, and Niklas Luhmann. A summary can be found in Schimank (1996). The law and legal doctrine itself are also covered by this autonomization process (see Part 4 below on this point) with the consequence that legal positivism is becoming predominant.

10. Luhmann (1981), p. 22.

11. Luhmann (1986), p. 180.

12. Günther (1976), pp. 283-306.

13. Weber (1968), pp. 605ff.; cf. Schluchter (1988), pp. $299 \mathrm{ff} ., 302$.

14. Concerning the different rationality claims in greater detail: Teubner (1996), pp. 199-220 with further references.

15. Cf. Eidenmüller (1995).

16. An informative summary can be found in Brodocz \& Schaal (2009).
} 
foundation as the core of political rationale demands to be implemented everywhere in the law. In their turn, sociological role theories, which were developed for the micro-level of society, are extrapolated to the macro-level, raising the reciprocity of social roles to the status of a general social norm. ${ }^{17}$ Again, moral criteria typically take the form of specific interactions as a demonstration of mutual respect. And yet the social theories of moral philosophy claim regulatory sovereignty over social (nowadays, principally ecological) issues and demand to be implemented in the form of legal norms. ${ }^{18}$ Finally, social theories are also being developed in science itself, for instance in critical rationalism. Such theories insist on the impartial search for truth as the core of scientific rationality, and limit social theories to diagnosis and prognosis. Nevertheless, they demand the general scientification of the law in a process of "technocratic universalization."19

At the Laboratorium Weimar, where the loss of a general social orientation was seen in the law, the pluralization of social theories and law reached its high point. Faced with the accelerating pluralism of social theories-sociology, economics, political sciences, social philosophy-German jurisprudence embarked upon some bold experiments. The great controversies concerning constitutional theories (Carl Schmitt, Hans Kelsen, Hermann Heller), the dispute surrounding the alternative economic constitution or economic democracy (Franz Böhm and Hugo Sinzheimer), the invention of legal sociology, "Free Law" and the "Jurisprudence of Interests," the competing approaches of sociological jurisprudence, the "economic viewpoint" in the law, and "political justice" are an expression of this pluralism. In particular, it is the acquisition of independent status by autonomous areas of the law (especially economic law and labour law) that bears witness to the huge influence which the pluralization of social theories has had on the pluralization of the law itself. ${ }^{20}$

However, German law abruptly abandoned this pluralism of social theory and law when, under massive pressure from the political sphere, it became subject to the monopolistic claims of a single Weltanschauung. During the low points of the more recent history of German law, totalitarian social theories were successful in imposing their normative rules upon the law whenever these rules were at the same time supported by political systems. In the twentieth century, the law in Germany succumbed more than once to the temptation to subject itself to just such an "imperialism" of one social theory, basing not only its fundamental structures but even single norms on the requirements of whatever leading political theory was dominant at the time.

The racial theory of National Socialism was the first and also the most horrifying low point in terms of the dominance of a political theory over the law. ${ }^{21}$ Following the theory catastrophe in 1945, the relationship of the law to social theories in Germany led in the direction of two opposing and extreme positions. In the east, under massive political pressure, another totalitarian social theory, dialectical materialism, took control of law and state-with fatal

17. Dahrendorf (1958); Mead (1973).

18. The praeceptor Germaniae postbellicae knows how to answer almost any legal question with the authority of social theory; Habermas (1992), passim.

19. Albert (1993).

20. Concerning developments in the twentieth century in private law: Wieacker (1967), pp. 543ff., 558ff.; in public law: Stolleis (1999) pp. 90ff. (constitutional law doctrine and constitution), 153ff. (concerning the dispute over method in Weimar), 216ff. (differentiation of administrative law).

21. Cf. Rüthers (2004). 
consequences for the rule of law. ${ }^{22}$ The west, by contrast, responded to the unspeakable theory/law symbioses of fascism and real socialism with a different extreme: a kind of "immune reaction" of the law against any invasion by the "bacillus" of social theory. ${ }^{23}$ Having presumably become wiser after this twofold experience, legal doctrine in the Federal Republic, which regarded itself as autonomous, rigorously fought off all alien influences of social theory. This self-imposed defence against any kind of interdisciplinarity remained unshaken even by the brief yet feverish attacks of social theory which occurred in 1968 ; indeed, the phenomenon of "sociology before the gates of jurisprudence," which was feared to be a reversion to totalitarianism, further increased the trend towards the "selfimmunization" of legal doctrine. ${ }^{24}$ In legal comparison it is astonishing how extensively the law opened itself up to the social sciences in other legal systems, particularly in the common law. Foreign observers are quite disconcerted to register how German jurisprudence, which because of its strong theoretical orientation enjoyed international respect in the nineteenth and early twentieth centuries, went on to deliberately narrow its focus to mere doctrine. ${ }^{25}$ It is ironic that German law in the postwar period, in its state of profound uncertainty, followed many international influences, with a particular preference for the American legal world, although it resolutely turned away from the numerous "law and ..." movements which predominated in the US.

There was, however, one exception. For in the 1970s and 1980s, one social theory with a claim to sole representation, which had already for some time dominated all areas of the law as a "leading science" in the US, enjoying massive political support and an abundant flow of private financing, appeared on the scene in Germany as well. Transaction cost theory, the theory of property rights, public choice, and economic analysis of the law are various movements in economic theory which aim to substitute the worn-out concept of justice with the ideal of the economic efficiency of the law. ${ }^{26}$ These movements claim to entirely supersede the former orientation of the law with its basis in moral philosophy, and refuse to countenance any other social theories whatsoever. They self-confidently and openly profess a kind of "theory imperialism," permitting interdisciplinarity (for example in institutional economics), but only on their own terms. However, after economic theories had over a period of 30 years succeeded in expanding massively into all areas of life, right through to the economic analysis of love relationships and religious faith, ${ }^{27}$ there occurred-in the financial crisis of 2008 - the third theory catastrophe, under the effects of which the interpretational monopoly of economics in many disciplines collapsed. However, the question of whether this catastrophe also marks the end of the imperialism of economic thought in the law remains undecided.

22. Cf. Stolleis (2009), pp. 28ff., 43ff.

23. Incisive criticism on this point by Wiethölter (1968), pp. 10, 27f., $39 \mathrm{ff}$.

24. Lautmann (1971).

25. "German jurists once wrote short but profound treatises like those of Puchta and Windscheid which attempted to explain the foundational principles of private law. Now, many German academics write contributions to long multi-volume treatises, each volume divided into a multitude of subsections and each subsection written by a different author ... Die Einheit der Rechtsordnung is either left to take care of itself or is handled by cross-references" Gordley (2008), p. 222.

26. A brief presentation of legal economics can be found in Butler (2011). Admittedly, legal economics has not so far achieved a position of dominance over legal thinking in Germany in the same way as it has in the US. One probable reason for this is the self-immunization tendencies of doctrine to which we have referred.

27. Particularly radical Gary Beckers, cf. Pies and Beckers (1998). 


\subsection{The Distanced Approach}

What the law needs in its relationship with social theory, following such abrupt changes between heights and depths, is a distanced approach. Admittedly, in the light of these three catastrophes, the dedicated self-immunization of legal doctrine in Germany after the war appears to be almost the only option. Yet there is a possible alternative: transversality. In philosophy, transversality was developed as a process for dealing with the post-modern plurality of discourses which has followed the collapse of the "grands recits." ${ }^{28}$ Transversality in the law would mean: the law recognizes that, under extreme differentiation of society, there is no justification for the existence of any single generally valid social theory, but only for a multiplicity of theories of social areas which are equal in terms of their origin. These derive their justification from their co-existence, i.e. from the high level of autonomy and the simultaneous reciprocal interdependencies of different social rationalities. The law would then reject not only its one-sided economization, but also its one-sided politicization, sociologization, scientification, and moralization. It would defend itself against any claim to totality of any theory. However, it would accept the intrinsic right of social theories that exist side by side. It would transform — and herein lies the challenge- the new plurality of language-games into the formation of legal concepts and the formulation of norms. This is possible if the law insists on the partiality of the various social theories and only opens itself up to their influence to the extent that they make statements which are valid for their part-area.

However, transversality means more than just recognizing the territorial autonomy of the theories associated with different part-areas. The proper response to the interconnectedness of social part-areas, which is associated with their autonomy, must be a systematic exploration by the law of the inner logic of all competing part-area theories. ${ }^{29}$ Max Weber anticipated this transversality when he spoke of a "chain of final decisions" which is inevitable in the new polytheism, decisions which situationally have to be taken over and over again as we pass through the claims of different rationalities. ${ }^{30}$ This would not be any arbitrary "pick and choose," but a self-imposed obligation to carefully examine the claims of all theories in order to do justice to the plurality of social rationalities.

Transversal reason in the law would categorically reject the claim to totality currently asserted by economic theories, while at the same time acknowledging their relative internal law as a self-description of the economic system. The autonomy and simultaneous interconnectedness of part-area theories would be properly taken into account if the primary relevance of economic expertise is acknowledged in economic law, which would, however, at the same time mean that within economic law other social theories are also legally relevant in a secondary sense. ${ }^{31} \mathrm{~A}$ similar principle applies in respect of political theories of the law, such as John Rawls's theory of justice, which can claim primary (but not exclusive) validity only in regard to the field of political constitution, or Habermas's discourse theory, which has

28. Particularly by Welsch (1996).

29. Particularly emphasized by Wiethölter, for whom the law is only abreast of the times if it has thoroughly processed the messages of systems sociology, critical theory, and economic institutionalism; Wiethölter (1995), pp. 95f. See further, Wielsch (2009), pp. 67-76.

30. Weber, supra note 13, pp. 507f.; on that point see Schluchter, supra note 13, pp. $339 \mathrm{ff}$.

31. An exemplary study is offered by Wielsch (2008), who in regard to the law of intellectual property on the Internet initially has recourse to economic theory, but then turns to competing social theories in order in particular to do justice to political, scientific, and artistic requirements. 
arrogated to itself the status of a social theory but which must be demoted to that of a moral theory of interaction in the real world, and can only in that context aspire to discursive rationality. Even systems theory (which is the one I personally favour) cannot lay claim to becoming a new "super-theory" and thus a leading science for the law, for it is only a partial theory of social communication, its differentiation and its interdependencies-a specialist in regard to the general, so to speak-which expresses no preference for any of the partial rationalities of the modern age, and certainly does not develop any partial rationality of its own with a claim to sole representation, but instead takes as its central theme the equal validity of different social rationalities.

Let us return to the subject of "publication bias." What does the distanced approach of transversality mean in regard to the legal classification of a public-private network, in which pharmaceutical companies, academic institutions, and public bodies co-operate in order to develop a new drug? The starting point is that a new kind of phenomenon such as a PPP network cannot be satisfactorily covered either by the law of contract or by social law. Neither the legal concept of the contractual purpose nor that of the corporate purpose does justice to the aims of a network of different institutions. On the contrary, as numerous authors have come to agree, a separate legal concept has to be developed, that of the "network purpose." 32 Here, the law readily opens itself up to the analyses of economic transaction costs theory, according to which rational actors choose the novel form of the network when it offers advantages in terms of transaction costs by comparison with the structures of contractual or corporate law. ${ }^{33}$ But, as soon as the economic theory goes beyond this and insists that the network purpose is exclusively based on minimizing transaction costs, and if in addition it tries to hand over the regulation of conflict principally to private governance in the network, rejecting any intervention by state law on grounds of inefficiency, ${ }^{34}$ the law must oppose the economic monopoly on interpretation. Only in the transversal examination of other social theories does it become clear that the legal concept of the network purpose covers an area of greater complexity than any mere minimization of transaction costs. It is to be understood as a multiple orientation, embodying a commitment to the various individual projects of the network participants, on the one hand, and on the other hand to the overarching project of the network as a whole. ${ }^{35}$ With the transversal approach, the law successively examines the impulses provided by economic, political, sociological, and ethical theories, and other subordinate theories, coming to an understanding of intersystemic networks as an organizational arrangement in which the conflict between different social rationalities is actually institutionalized. A legal concept of the network purpose which is defined in this way places an obligation on the actors to adjust their behaviour to different and contradictory logics of action. In the case of the public-private research network, the participants are required simultaneously to take into account four mutually exclusive categorical imperatives, specifically the contradictory requirements of economic profitability, scientific knowledge, medical standards, and the political focus on the common good. In fact, as various social theories have stated, networks appear as a result of their hybrid nature to be

32. E.g. Grundmann (2007), pp. 720, 729ff.; from a comparative law perspective, see Cafaggi (2011), p. 11.

33. Gómez (2011), pp. 22, 25; Williamson (1985), pp. $180 \mathrm{ff}$.

34. Williamson (1991), pp. $273 \mathrm{ff}$.

35. Concerning double attribution in networks from the perspective of the social sciences and the law, see Teubner (2004a), pp. 120ff., including detailed verification. 
almost tailor-made for absorbing several contradictory rationalities within themselves, permitting mutual interference without any hierarchical classification. ${ }^{36}$

Can a legal network constitution respond to such challenges? Instead of merely promoting the minimization of transaction costs, a legal constitution of networks will develop principles of institutional autonomy, fundamental rights, procedural fairness, the rule of law, and political responsibility in these mixed public-private configurations. ${ }^{37}$ The legal form of the network purpose ought not to recognize any theory as having a monopoly-there must be no exclusivity for the reduction of transaction costs, or for policy orientation, or for the acquisition of scientific knowledge, or for ethical standards of behaviour. Instead, this legal form must seek to cover the multidimensionality of the networks by exploring different social theories. It is forbidden for the law to accept the dominance of any other social part-rationality.

A similar multiple orientation has already been developed in the legal concept of "corporate group interest." 38 This is hardly surprising, for corporate groups are networks in just the same way as the contractual combinations which we are addressing here. But, by contrast with the law on corporate groups, which in addition to the legal guarantees of the autonomy of subsidiaries also protects the purely economic interests of the subsidiaries against the parent company and vice versa, ${ }^{39}$ a great deal more is at stake in the case of intersystemic networks. Not just the acquisition of profits, but also the institutional integrity of research institutions, medical facilities, private trusts, and public administration have to be respected in the decentralized structure of a network. While it remains expedient in the law on corporate groups to formulate a common economic corporate interest which is common to all members of a group in the form of procedural and substantive legal norms, a network purpose in PPP co-operations can only consist in a process of searching for an area of compatibility between different rationalities.

This associative purpose of intersystemic networks finds its legal embodiment-in parallel with the contractual purpose and the company purpose-inter alia in duties of loyalty for the network participants which are reinforced by means of sanctions. ${ }^{40}$ These duties apply both in regard to the other participants (and therefore require their separate interests to be taken into consideration) and also in regard to the network as a whole (and are therefore directed towards the success of the project). ${ }^{41}$ The manipulations of the research results, which in the circumstances of the case we have described were carried out, on the basis of their respective separate interests, by the communication agency in co-operation with the pharmaceutical company and the scientific establishment responsible for carrying out the clinical studies, were a blatant violation of both forms of the duty of loyalty, and give rise to very serious legal sanctions. Unlike the contractual purpose or the company purpose, the network purpose

36. Concerning conflicts of rationalities in intersystemic networks, see Amstutz (2006), pp. 121ff.; Teubner (2004b), pp. $40 \mathrm{ff}$.

37. Teubner, supra note 36.

38. Cf. Emmerich \& Habersack (2013), §311 Rn. 47-50, §311 Rn. 77-81, and §18 Rn. 7; Hoffmann-Becking (2012), pp. 441ff.; for the European discussion on "corporate group interest," see Drygala (2013), pp. 198-210.

39. Only the approaches of sociologically informed corporate group law go beyond this monotextural orientation; see e.g. Amstutz (1993).

40. The external liability of networks is the other area of the law for which network-adequate norms have to be developed; cf. Teubner (2004a), pp. 204ff.

41. Providing a detailed legal comparison, Weitzenboeck (2012), pp. $186 \mathrm{ff}$. 
imposes an obligation to promote the different rationalities involved and at the same time to balance them against each other. By contrast with the traditional balancing of interests in the individual case, the result of the transversality approach would be that the autonomy of different rationalities, and the way in which they are interconnected, are examined in a legal balancing process.

\section{THESIS 2: RESPONSIVENESS}

The distanced approach is also recommended in another respect. If the law, in the transversal process, has reached a decision through its contacts with social theories, then these require that their findings be taken over into the law without being falsified in any way. Legal doctrine in particular (the scientific character of which is in any case dubious) appears to be guilty of obfuscation here. ${ }^{42}$ Accordingly, inspired by Jhering's polemic against conceptual jurisprudence, American legal realism has ridiculed traditional legal doctrine as "transcendental nonsense" and replaced it with a conception of the law (based on political theory) as a consequence-oriented social policy. Critical Legal Studies has intensified the "trashing" of doctrine on the basis of critical social theory and has demanded the open politicization of legal conflicts. The principal representative of economic legal theory, Richard Posner, has denied any autonomous contribution by legal doctrine to the rational establishment of norms, and has called for the obsolete moral-political orientation to be replaced by criteria of economic efficiency. Other authors in turn have demanded the unity of the social sciences, so that jurisprudence as a "real science" is only a subsection of the social sciences and has no independent status. ${ }^{43}$

This must be vigorously contested with the statement that any authentic transfer of knowledge from social theory into the law is an impossibility. It cannot succeed because of the unyielding autonomy of the legal system. This is the lesson not only of traditional legal doctrine, but also of advanced systems theory. ${ }^{44}$ The functional differentiation of society, which we have already addressed, encompasses the law itself, as well as other social systems. Supported by the exclusive validity of the right/wrong "binary code," the law develops a complex structure of concepts which we call "doctrine," which is in fact incommensurable with scientific theories. The code of law, which is different from other "binary codes" of society, forms the basis of the uncircumventable autonomy of legal doctrine, which categorically excludes any one-to-one takeover of social theories.

Nevertheless, in the light of the interdependence of social part-rationalities, an interconnection between social theories and doctrine is necessary. However, this interconnection can only arise on the basis of autonomy on both sides. It is therefore misleading to speak of the relative autonomy of the law; on the contrary, a relationship of mutual enhancement exists between the autonomy of the law and its interdependence with other social systems. ${ }^{45}$

\footnotetext{
42. Concerning the problematic question of the scientific nature of jurisprudence, a summary of the discussion is provided by Röhl \& Röhl (2008), pp. 79ff.

43. Loci classici, Cohen (1935), pp. 809-49; Kennedy (1975), pp. 1685-778; Posner (1987), pp. 761-80; Albert (1993).

44. Luhmann (1993), pp. 538ff; see further, Vesting (2007), pp. 141ff.

45. The distinction is important. Relative autonomy means that dependence and independence are based on the same mechanism; a relationship of mutual enhancement is possible if dependence and independence are attributable to
} 
In the first place, this means a strict division of tasks between two independent search processes: social theories provide structural analyses of social phenomena; they identify social problems which are generated by these phenomena in their environment, and they are able to provide directional information aimed at finding possible solutions to the problems, which they subject to a functional comparison. This is something that legal doctrine can connect with, if (diachronically in the path dependency of historically developed legal concepts, and synchronically in the context of the code of law and existing law programmes) it develops independent norms.

The interconnection between law and social sciences goes beyond the mere staking out of territorial boundaries at the point when legal doctrine starts to carefully examine different legal institutions in order to determine whether, in terms of their internal normative logic, their "inner basis," they are capable of responding sensitively to the structures and problems of the social phenomena as perceived by the law. These subtle search operations, which are performed with the aid of the sensory concepts of doctrine, are to be referred to here using the term "responsiveness." 46 The responsiveness of the law is not to be achieved before the forum of the social sciences, which ensure the authentic use of the term, or before the forum of a superordinate third instance acting as an intermediary between law and social theory, but only before the "forum internum" of the law itself. In a complex process of examination, the law allows itself to be challenged by the external problem analyses of social theories, but only if they are usable according to its own selection criteria, and it reconstructs these internally in its own language, in which it can then match problems and solutions together. Only when this process of reconstruction places legal argumentation in a position where it can distinguish within the law between norms and facts, between legal concepts and social interests, has a point been reached where the law is able to raise the question of social adequacy; in other words, the question of whether legal decisions do justice to those aspects of the outside world as these have been internally reconstructed. ${ }^{47}$ To that extent, the legal reception of social theories is never an authentic takeover, but always a "re-entry" of the system-environment difference, through which an imaginary space arises in the law, i.e. it is always an internal legal reconstruction of external demands made by society, by people, and by nature. ${ }^{48}$ Responsiveness, as the law's capacity to be challenged by social theories, is by no means a "floodgate" through which—as Niklas Luhmann puts it—“social knowledge could increasingly and seemingly without restraint be able to flow into the law. Quite the opposite: the emphasis is on system subjectivity, if such a formulation can be permitted, and thus on the unavoidable system relativity of all perspectives." 49 The conflict between autonomous law and autonomous social theory is in principle not insuperable, indeed it is to be desired. ${ }^{50}$ It can only (to use an exaggerated formulation) be overcome by means of a productive misunderstanding within the law. The misunderstanding is unavoidable, and

(F'note continued)

different mechanisms. The independence of the law is based on the interlinking of legal acts, while dependence is based on the challenges presented to the programmes of the law.

46. Locus classicus, Nonet \& Selznick (1978).

47. Concerning "enaction" of the environment as an alternative to its "representation," see Varela (1992), pp. 235ff.

48. Concerning the connection between "re-entry" and "imaginary space," see Brown (1997); in relation to the application of the law and its environments, Umwelten, see Luhmann (1993), pp. $76 \mathrm{ff}$.

49. Luhmann (1985), p. 7.

50. The conflicts need to be nurtured, not eliminated; cf. Hensel (2009), pp. $521 \mathrm{ff}$. 
becomes productive when legal doctrine treats social theories as external "challenges," but instead of dismissing these in splendid isolation reconstructs them within the law, forming its own concepts, and responds to them with the autonomous formation of norms.

If the "translation" of social theory into legal doctrine is undertaken in this way, then it has the potential to generate added value in terms of legal doctrine. ${ }^{51}$ The process occurs not as a mere transfer of identical meaning in another language, but in such a way that the law's own terminology allows itself to be challenged, in accordance with the conditions of its inner development logic, by social theory constructs, and thereupon to be inspired to create quite differently structured new formations. It is only this three-stage process of challengereconstruction-norm setting that generates the doctrinal added value that cannot be achieved either in the self-immunization of legal doctrine or in the direct transfer of social theory constructs into the law.

Where would the doctrinal added value lie within the PPP network with regard to the legal questions we raised at the start of this paper? "Network" is not a legal concept. There is no way that the efficiency principle, on the basis of which economists analyze networks as hybrids between market and hierarchy, is able to serve as a legal guiding principle, far less as a directly applicable legal norm in regard to networks. Neither can the principle of the "social embeddedness" of economic transactions, which sociologists emphasize as being a characteristic feature of networking. ${ }^{52}$ Instead, strict division of tasks is necessary. Network theories identify the idiosyncratic logic of action of networks, reveal the opportunities and risks of network-controlled forms of action, and open up alternatives for structural solutions that extend beyond market and hierarchy. Contractual law allows itself to be challenged thereby, reconstructs the problems associated with networks using the law's own concepts, and, on the basis of its own traditions of thought, develops independent norms and principles for networks which can be applied as appropriate legal solutions for the new kinds of co-ordination and liability problems that have arisen.

The real challenge of any responsive procedure consists in finding out which, among the various historically developed legal forms of private law, is most likely to have the normative potential for devising statutory definitions of offences and legal consequences for networkadequate rules. What legal form is capable of achieving, over and above the bilateral agreements concluded between the parties, a comprehensive legal commitment by all parties to the overall association that is being formed between them? The possibilities include a partnership formed under the Civil Code, a network agreement, a contractual basis [Geschäftsgrundlage], a contract for the protection of third parties, a combination of contracts. Structures based on company law are not satisfactory for networks, since they include the exclusive obligation in regard to the company purpose, and would have to classify the simultaneous orientation to individual purposes, which is a characteristic of networks, as unlawful. The construct of a network agreement concluded between all participants fails to appreciate the legal reality of networks, since it has to invent a multiplicity of legal fictions in regard to representation and authorization of all parties for all parties. ${ }^{53}$ A contractual basis

51. Concerning the connection between challenge, reconstruction, and symbolic added value generally, see Mölders (2012) pp. 18ff.; in relations between social theory / law, see Teubner (1998), pp. 250ff.

52. The term "network" in an economic context: Williamson (1991); in a sociological context: Powell (1996).

53. The construct of a separate network contract in Rohe (1998). 
has to be excluded because it is only directed towards execution and cannot generate any legal duties. ${ }^{54}$ A contract with protective effect in favour of third parties does generate binding effects in respect of third parties, but is not suited to multilateral relationships, and in terms of the criterion of proximity of performance and endangerment of legal interests it lacks the orientation towards contractual performance which is necessary in a network. ${ }^{55}$ The legal form of the combination of contracts, developed for the purposes of financed purchase agreements, proves to be the most suitable for networks, since it precisely illustrates the tension between the independent nature of the individual contracts and their reciprocal interlinking, it formulates the network-typical dual orientation towards network nodes and the network as a whole as a legal relationship, and it establishes three precisely delineated factual characteristics for the creation of an association: (i) the interconnecting nature of the contracts; (ii) the common contractual purpose; and (iii) the de facto co-operation, without any complete multilateral conclusion of a contract being necessary. ${ }^{56}$ Network versus connected contracts - this difference between analysis based on social theory and juristic classification holds the potential for generating the doctrinal added value we are seeking.

\section{THESIS 3: SELF-NORMATIVITY}

Finally, our "publication bias" case raises the most difficult problem of all in the form of the question: Can normative criteria be obtained from social science theories, in our case in regard to the fundamental rights effect in mixed public-private networks? Present-day advocates of the unity of theory and practice see this as their noblest task, i.e. to reveal, in an analysis of society as a whole, normative potentials for social development which provide guideline information for politics and law. ${ }^{57}$ And the normatively low-key sociological systems theory is required first of all to perform a "normative turn" if it wishes to make statements that are relevant to the law. ${ }^{58}$

Yet here too-for the third time- - we are forced by the functional differentiation of society to make a correction. This differentiation irrevocably destroys the old European unity of theory and practice, forcing science to operate within the constraints of an exclusive true/ false coding which does not allow that social theories can also (instead of mere cognitive statements) make normative statements in the code of politics, morality, or the law. The science system cannot in principle supply other action contexts with normative criteria. ${ }^{59}$ Normative recommendations are always trans-scientific issues. ${ }^{60}$

This self-restriction also - and in a particularly painful way-affects philosophy, from which the law (in spite of what Rawls and Habermas say) cannot expect any import of normativity. Philosophy cannot escape from the Münchhausen trilemma of the establishment of norms-infinite regress, curtailment, circularity. Ultimately, all attempts to establish

54. Grundmann (2008), pp. 227-44.

55. Lange (1998), pp. 195ff., 200.

56. Teubner (2004a), pp. 109ff.

57. A notable example being Habermas (1963), particularly pp. $231 \mathrm{ff}$.

58. Francot-Timmermans \& Christodoulidis (2011), pp. 187-90.

59. Luhmann (1990), pp. 627ff. The science system also develops normative orientations, but only for its own practice.

60. Weinberg (1972), pp. 209-22. 
norms run up against paradoxes. However, deparadoxation cannot be effected by philosophy in a normative guise, but only by social practices in communication and by individuals in their introspection. ${ }^{61}$ The consequence of this failure of theory is: self-normativity. This is achieved in two entirely different processes: the self-normativity of the law is formed in internal processes of the law, and the self-normativity of social practices (to which the law can have recourse) arises in processes outside the law.

The law itself is one of the social practices that generate self-normativity without being dependent on their scientific or philosophical basis. This conclusion is forced upon us by (to name a few important authors) Hans Kelsen's basic norm, Herbert Hart's internal view, and Niklas Luhmann's binary code of the law. ${ }^{62}$ Legal self-normativity functions as selfreproduction of normative standards on the basis of applicable law and as production of deviating norms according to the conditions in which the law operates. And it is only within the framework of this self-normativity of the law that social theory can become normatively relevant (although only in the context of challenge and reconstruction as described above).

However, legal self-reproduction only generates one kind of self-normativity, i.e. the selfnormativity that is internal to the law. Externally to the law, the self-normativity of other social practices supplements the internal production of norms, insofar as the law has recourse thereto. Social systems generate not only their own rationality, but also their own normativity. This has been demonstrated most clearly by Lon Fuller, who describes the morality of associations as an emerging phenomenon of social communication. Yet from Wittgenstein to Lyotard this insight has formed part of the acknowledged status of research in linguistic philosophy. The normativity of a large number of language-games is based on their life forms and is not accessible to any ultimate justification. In a very similar way, institutionalism identifies social practices as generators of sets of norms under the control of an idée directrice. ${ }^{63}$

At this point it becomes clear that the driving motive for the search for an interdisciplinary encounter between the law and social theories is certainly not contact with science, but contact with society. Over and above its self-normativity, the law seeks normative orientations in different environments and their norms, and in addition asks social theories to provide help. Yet upon closer inspection it emerges that much of what goes by the name of social theory is not a scientific theory in the strict sense, but a practice of reflection, or perhaps more accurately a doctrine of reflection, similar to theology and legal doctrine, which generates normative orientations in social practices.

Legal normativity also always develops in contact with these reflection doctrines of other part-areas of society. It is therefore important to avoid the scientific misunderstanding which is promoted by the programmes of sociological jurisprudence, political legal theory, or legal economics, which regard themselves as sciences. As important as the structural analyses of the social sciences are for the responsiveness of the law (as has been demonstrated above), nevertheless the focus is elsewhere here, on normative orientations which in principle cannot be provided by the impartial sciences, but only by normatively loaded "doctrines" of social action. Just as legal doctrine itself, or the mother of all doctrines, theology, are not sciences,

61. More on that point Teubner (2013).

62. Kelsen (1979), pp. 206f.; Hart (1961), pp. 55ff.; Luhmann (1993), pp. $165 f$ f.

63. Fuller (1983); Lyotard (1989); Hauriou (1965). 
but reflections of the social practices of law or religion which have been systematized as doctrinal systems, so large areas of business economics, economic science, and political science are also not parts of science, which has to observe the code of truth, but reflection doctrines of sectors of society, appearing in the guise of scientific social theories, i.e. doctrines concerning the right way to act in business, in industry, or in politics, sharing and informing the respective normative basic orientations of their practices. In any event, a clear internal differentiation ought to be made between the academic disciplines (just as a distinction is made in jurisprudence between legal theory as a reflection on practice and legal sociology as scientific observation of the law) into discourses which as reflection doctrines are allocated to the respective part-system of society, and discourses which as social theory in the strict sense are to be allocated to the science system.

What we are searching for here is therefore contact with the self-normativity of social practices, which are refined in the reflection doctrines of economic and social practice. ${ }^{64}$ As compared with the scientific misunderstanding referred to above, the gain is thus twofold. The orientation to social reflection doctrines provides a wealth of normative perspectives, from the idées directrices of social institutions, to social expectations, claims, entitlement to basic rights, and hopes of persons involved, to decentrally obtained insights of the social systems concerning their performance capability, to definitions of their overall social function. ${ }^{65}$ This could never be generated by "presupposition-free" and "prejudice-free" social theories, but neither could it ever be devised by legal doctrine on its own terms. At the same time, however, there are once again indications of distancing possibilities for the law, if it has to enforce its own "particular-universal" orientations by means of legal controls. The vessel that sails under the flag of the scientific approach as sociological jurisprudence, legal economics, legal politics, and legal ethics ought in reality to change its colours to reflect its legal handling of the conflict between different reflection doctrines.

To return once more to the subject of moral philosophy: Is it possible, then, to use Rawls or Habermas for the justification of legal norms? It depends. No, to the extent that they claim to produce a scientific social theory, since (contrary to their self-understanding) they are incapable of establishing any norms in the truth code of science. Yes, to the extent that they can be understood as participants in moral practice or political practice and are working on the reflection doctrines thereof. Even as such they are still not directly juristically relevant, but must first go through the legal filter of legal theory, doctrine, and judicial decision-making practice.

Let us return one final time to publication bias. What does the interplay between the self-normativity of the law and the self-normativity of social institutions mean as far as the third-party effect of fundamental rights in private networks is concerned? In short, what is required is for norms to be established for the institutional protection of expertise, on the one hand, and for the integrity of the health system, on the other hand, against the expansionary tendencies of economic rationality.

The normative content of the horizontal effect of fundamental rights cannot be established on the basis of social theory, but is initially a product of operations taking place inside the

64. Particularly noteworthy, the already institutionalized norms of the professions; on this point, with the results of empirical research, see Herberg (2014).

65. Karl-Heinz Ladeur in particular stresses repeatedly how heavily the law depends on a "social epistemology", i.e. on the knowledge of social practices; Ladeur (2006). See further Augsberg (2014). Concerning the "subcutaneous" influence of the decorum of art on the case-law concerning questions of personal rights; Steinhauer (2009), pp. 174ff. 
law. The principle of equality, as the fundamental principle of the self-normativity of the law, requires that the protection of fundamental rights be guaranteed not only vis-à-vis governmental instances, but also vis-à-vis private networks, if fundamental rights are similarly put at risk in situations involving private power. ${ }^{66}$ The manipulations in the network which trigger publication bias - the bans on publication and the falsification of research results - violate not only the fundamental right of academic freedom, but also the fundamental right to health. However, as is demonstrated by the vehement protests of those who uphold the sanctity of private law against any such kind of third-party effect, it is problematic whether any effective protection of fundamental rights can be achieved through a balancing of individual fundamental rights positions as envisaged by prevailing doctrine. ${ }^{67}$ One way out of this dilemma is to shift the task of protecting fundamental rights against private power from the individual level to the institutional level. The horizontal effect of fundamental rights (in our case, the right to academic freedom and the right to health) is then guaranteed not by individual rights positions on the basis of which legal action can be brought, but by organization and process. ${ }^{68}$

The question of what organization and what processes can be used to protect the institutions of science and the health-care system is then no longer answerable from inside the law. The normative content of institutional guarantees of fundamental rights can only be obtained from outside the law, from the self-normativity of social practice. Science and the health-care system, in their separate codes and programmes, give rise to normative orientations which are not the same as the conventional opinions of individuals, but have an institutional character. ${ }^{69}$ An institutional normativity of this kind is embedded in historically developed structures, reactivated in the reflection doctrines of science and the health-care system, and re-formed in "political" deliberative decisions, before they are absorbed by the law.

As far as publication bias manipulations are concerned, the reflective discourses of science and health care have in fact devised an institutional alternative to individual protection, the legal formulation of which is to be recommended: trial registration as a third-party effect of fundamental rights through organization and process. ${ }^{70}$ Public registers of studies and results are being set up, which cover all aspects of studies from their very beginning in order to facilitate transparency and control. ${ }^{71}$ At the same time, specialist journals are making the registration of all studies carried out a precondition for publication. ${ }^{72}$ Clinical studies in respect of products that are intended for distribution on the market must first have been registered on the clinical trials register with all study results.

66. Maunz \& Dürig (2013), Art. 1 Sec. 3GG, pp. 59-65.

67. Particularly critical is Zöllner (1996).

68. In the third-party effect discussion, individual fundamental rights are usually balanced against each other; the institutional dimension of fundamental rights is rarely used here; cf. Hensel, supra note 50, pp. 517ff.

69. Vesting, supra note 44, pp. 95ff. speaks here of "social conventions and implicit knowledge."

70. The US functions as a model with the FDA Amendments Act of 2007 (FDAAA) (2007), online: <http://frwebgate. access.gpo.gov/cgi-bin/getdoc.cgi?dbname=110_cong_public_laws\&docid=f:publ085.110.pdf >, pp. 110-85, §801 (last accessed 25 May 2014).

71. Initial examples are provided by the US government register ClinicalTrials.gov (2004) and the Deutsche Register Klinischer Studien at the Universitätsklinikum Freiburg, online: <http://www.germanctr.de> (last accessed 25 May 2014).

72. De Angelis (2004); there are also some Internet journals which primarily publish negative studies, e.g. Journal of Negative Results in Biomedicine, online: <http://www.jnrbm.com/>. 


\section{CONCLUSION}

What we have attempted to show here in a general way, using the example of the horizontal effect of fundamental rights in semi-private networks, is that at the point where social theory meets law an added value can be generated in terms of legal doctrine if the precarious relationship between autonomy and interconnectedness in three different dimensions is respected.

1. Transversality draws conclusions from the autonomy of different incommensurable social theories and their mutual interconnectedness. The law denies any monopoly claim and selects points of contact in a transversal exploration.

2. Responsiveness insists on the autonomy of legal doctrine vis-à-vis social theory and takes account of their mutual interconnectedness, with the law opening itself up to the challenges posed by social theories and drawing inspiration from this for normative innovation.

3. Self-normativity: the law achieves normative orientation not from social theory, but solely from internal processes of the law and at the same time from the self-normativity developed by the reflection doctrines of other social systems.

Specifically: in the circumstances of our case, different doctrinal constructs-a network purpose which is distinct from the contractual purpose and the company purpose, connected contracts as a legal concept for social networks, and an institutional guarantee of the horizontal effect of fundamental rights through organization and process in the form of trial registration — can be regarded as socially adequate developments of the law which arise in the distanced approach to network theories adopted by the law.

\section{REFERENCES}

Albert, Hans (1993) Rechtswissenschaft als Realwissenschaft: Das Recht als soziale Tatsache und die Aufgabe der Jurisprudenz, Baden-Baden: Nomos Verlagsgesellschaft.

Amstutz, Marc (1993) Konzernorganisationsrecht: Ordnungsfunktion, Normstruktur, Rechtssystematik, Bern: Stämpfli.

Amstutz, Marc (2006) "Die Verfassung von Vertragsverbindungen." 89 Kritische Vierteljahresschrift für Gesetzgebung und Rechtsprechung 105-30.

Applegate, William B., Curt D. Furberg, \& Robert P. Byungton (1997) "The Multicenter Isradipine Diuretic Athersclerosis Study (MIDAS)." 277 Journal of the American Medical Association 297-98.

Augsberg, Ino (2014) Informationsverwaltungsrecht: Zur kognitiven Dimension der rechtlichen Steuerung von Verwaltungsentscheidungen, München: Mohr Siebeck.

Brodocz, André, \& Gary Schaal (2009) Politische Theorien der Gegenwart, Opladen: UTB.

Brown, George S. (1997) Gesetze der Form, Lübeck: Suhrkamp Verlag.

Butler, Brian E. (2011) Law and Economics, Internet Encyclopedia of Philosophy, online: < http:// www.iep.utm.edu/law-econ/> (last accessed 25 May 2014).

Cafaggi, Fabrizio (2011) "Introduction," in F. Cafaggi, ed., Contractual Networks, Inter-Firm Cooperation and Economic Growth, Cheltenham: Edward Elgar Publishing, 1-18.

Carl von Savigny, Friedrich (1840) System des heutigen römischen Rechts, Band 2, Berlin: Kulturbesitz.

Castells, Manuel (2000) The Rise of the Network Society, Oxford: Wiley-Blackwell.

ClinicalTrials.gov (2014) "US Government Register," online: <http://ClinicalTrials.gov> (last accessed 25 May 2014). 
Cohen, Felix S. (1935) "Transcendental Nonsense and the Functional Approach.” 35 Columbia Law Review 809-49.

Dahrendorf, Ralf (1958) Homo Sociologicus: Ein Versuch zur Geschichte, Bedeutung und Kritik der sozialen Rolle, Wiesbaden: VS Verlag für Sozialwissenschaften.

De Angelis, Catherine (2004) "Clinical Trial Registration: A Statement from the International Committee of Medical Journal Editors." New England Journal of Medicine 606-7.

Drygala, Tim (2013) "Europäisches Konzernrecht: Gruppeninteresse und Related Party Transactions." 16 Die Aktiengesellschaft 198-210.

Eidenmüller, Horst (1995) Effizienz als Rechtsprinzip, Tübingen: Mohr.

Emmerich, Volker, \& Mathias Habersack (2013) Aktien- und GmbH-Konzernrecht-Kommentar, 7th edn., München: C.H. Beck.

Eyding, Dirk (2010) "Reboxetine for Acute Treatment of Major Depression: Systematic Review and Meta-analysis of Published and Unpublished Placebo and Selective Serotonin Reuptake Inhibitor Controlled Trials." British Medical Journal 341: C4137, 1-14.

Francot-Timmermans, Lyana, \& Emilios A Christodoulidis (2011) "The Normative Turn in Teubner's Systems Theory of Law." 40 Rechtsfilosofie \& Rechtstheorie 187-90.

Fuller, Lon (1983) Principles of Social Order: Selected Essays of Lon L. Fuller, Durham, NC: Duke University Press.

Gómez, Fernando (2011) "Cooperation, Long-Term Relationships and Open-Endedness in Contractual Networks," in F. Cafaggi, ed., Contractual Networks, Inter-Firm Cooperation and Economic Growth, Cheltenham: Edward Elgar Publishing, 21-38.

Gordley, James (2008) "The State's Private Law and Legal Academia," in N. Jansen \& R. Michaels, eds., Beyond the State: Rethinking Private Law, Tübingen: Mohr Siebeck, 219-32.

Grundmann, Stefan (2007) "Die Dogmatik der Vertragsnetze." 207 Archiv für die civilistische Praxis 718-67.

Grundmann, Stefan (2008) "Vertragsnetz und Wegfall der Geschäftsgrundlage," in L. Aderhold, eds., Festschrift für Harm Peter Westermann zum 70. Geburtstag, Köln: Verlag Otto Schmidt, 227-44.

Günther, Gotthard (1976) "Life as Poly-Contexturality," in Gotthard Günther ed., Beiträge zur Grundlegung einer operationsfähigen Dialektik I, Hamburg: Meiner, 283-306.

Habermas, Jürgen (1963) Theorie und Praxis: Sozialphilosophische Studien, Frankfurt: Suhrkamp Verlag.

Habermas, Jürgen (1992) Faktizität und Geltung: Beiträge zur Diskurstheorie des Rechts und des demokratischen Rechtsstaats, Frankfurt: Suhrkamp Verlag.

Hart, Herbert L.A. (1961) The Concept of Law, Oxford: Clarendon.

Hauriou, Maurice (1965) Die Theorie der Institution, Berlin: Duncker \& Humblot.

Hensel, Isabell (2009) "Grundrechtskollisionen in der Stiftungsuniversität: Überwältigte Einheit oder organisierte Vielfalt," in G.P. Callies, ed., Soziologische Jurisprudenz: Festschrift für Gunther Teubner zum 65. Geburtstag, Berlin: De Gruyter, 509-30.

Herberg, Martin (2014) "Professionalisierung als Mechanismus von Global Governance: Zur Rolle des 'reflexiven Praktikers' in der globalen Steuerungsarchitektur," in G. Winter, ed., "Ex Rerum Natura Ius": Sachzwang und Problemwahrnehmung im Umweltrecht, Baden-Baden: Nomos, forthcoming.

Hoffmann-Becking, Michael (2012) "Gibt es das Konzerninteresse?," in Bernd Erle, ed., Festschrift für Peter Hommelhoff, Köln: Schmidt, 433-46.

Kelsen, Hans (1979) Allgemeine Theorie der Normen, Wein: Manz.

Kennedy, Duncan (1975) "Form and Substance in Private Law." 89 Harvard Law Review 1685-778.

King, Ralph T. (1996) "Bitter Pill: How a Drug Firm Paid for University Study, Then Undermined It." Wall Street Journal v.12.04.

Ladeur, Karl-Heinz (2006) Der Staat gegen die Gesellschaft: Zur Verteidigung der Rationalität der Privatrechtsgesellschaft, Tübingen: Mohr Siebeck Verlag.

Lange, Knut W. (1998) Das Recht der Netzwerke, Recht und Wirtschaft, Heidelberg: Recht und Wirtschaft.

Lautmann, Rüdiger (1971) Soziologie vor den Toren der Jurisprudenz: Zur Kooperation der beiden Disziplinen, Stuttgart: Kohlhammer. 
Luhmann, Niklas (1981) Politische Theorie im Wohlfahrtsstaat, München: Olzog.

Luhmann, Niklas (1985) "Einige Probleme mit 'reflexivem Recht'." 6 Zeitschrift für Rechtssoziologie $1-18$.

Luhmann, Niklas (1986) "Die Codierung des Rechtssystems.” 17 Rechtstheorie 171-203.

Luhmann, Niklas (1990) Die Wissenschaft der Gesellschaft, Frankfurt: Suhrkamp.

Luhmann, Niklas (1993) Das Recht der Gesellschaft, Frankfurt: Suhrkamp.

Lyotard, Jean-François (1989) Der Widerstreit, 2. Aufl., München: Wilhelm Fink Verlag.

Maunz, Theodor, \& Günter Dürig, eds. (2013) Grundgesetz, Loseblatt-Kommentar, München: Beck.

Mead, George Herbert (1973) Geist, Identität und Gesellschaft, Frankfurt: Suhrkamp.

Mölders, Marc (2012) "Kluge Kombinationen: Zur Wiederaufnahme systemtheoretischer Steuerungskonzepte im Governance-Zeitalter." 33 Zeitschrfit für Rechtssoziologie 5-30.

Nonet, Phillippe, \& Philip Selznick (1978) Law and Society in Transition: Toward Responsive Law, New York: Transaction Publishers.

Pies, Leschke, \& Gary Beckers (1998) Ökonomischer Imperialismus, Tübingen: Mohr Siebeck.

Posner, Richard A. (1987) "The Decline of Law as an Autonomous Discipline: 1982-1987." 100 Harvard Law Review 761-80.

Powell, Walter (1996) "Weder Markt noch Hierarchie: Netzwerkartige Organisationsformen," in P. Kenis \& V. Schneider, eds., Organisation und Netzwerk. Institutionelle Steuerung in Wirtschaft und Politik, Frankfurt: Campus, 213-71.

Rohe, Mathias (1998) Netzverträge: Rechtsprobleme komplexer Vertragsverbindungen, Tübingen: Mohr Siebeck.

Röhl, Klaus, \& Hans C. Röhl (2008) Allgemeine Rechtslehre: Ein Lehrbuch, 3. Aufl., Köln: Verlag Franz Vahlen.

Rüthers, Bernd (2004) Die unbegrenzte Auslegung. Zum Wandel der Privatrechtsordnung im Nationalsozialismus, Tübingen: Mohr Siebeck.

Schimank, Uwe (1996) Theorien gesellschaftlicher Differenzierung, Opladen: Leske und Budrich.

Schluchter, Wolfgang (1988) Religion und Lebensführung, Band 1, Frankfurt: Suhrkamp.

Schott, Gisela (2010) "Finanzierung von Arzneimittelstudien durch pharmazeutische Unternehmen und die Folgen, Teil 1: Qualitative systematische Literaturübersicht zum Einfluss auf Studienergebnisse, -protokoll und -qualität.” 107 Deutsches Ärzteblatt International 279-85.

Song, Hooper, \& Yoon K. Loke (2013) "Publication Bias: What Is It? How Do We Measure It? How Do We Avoid it?" Open Access Journal of Clinical Trials 71-81.

Song, Parekh, \& Lee Hooper (2010) "Dissemination and Publication of Research Findings: An Updated Review of Related Biases, Technology Assessment." 14 Health Technology Assessment $1-220$.

Steinhauer, Fabian (2009) Bildregeln: Studien zum juristischen Bilderstreit, München: Wilhelm Fink Verlag.

Stolleis, Michael (1999) Geschichte des öffentlichen Rechts in Deutschland Band 3: Staats- und Verwaltungsrechtswissenschaft in Republik und Diktatur 1914 bis 1945, München: Beck.

Stolleis, Michael (2009) Sozialistische Gesetzlichkeit. Staats- und Verwaltungsrechtswissenschaft in der DDR, München: C.H. Beck.

Teil 2 (2010) "Qualitative systematische Literaturübersicht zum Einfluss auf Autorenschaft, Zugang zu Studiendaten sowie-registrierung und Publikation." 107 Deutsches Ärzteblatt International 295-301.

Teubner, Gunther (1996) “Altera Pars Audiatur. Das Recht in der Kollision anderer Universalitätsansprüche, Archiv für Rechts- und Sozialphilosophie.” 65 Beiheft 199-220.

Teubner, Gunther (1998) "Vertragswelten: Das Recht in der Fragmentierung von Private Governance Regimes." 17 Rechtshistorisches Journal 234-65.

Teubner, Gunther (2004a) Netzwerk als Vertragsverbund: Virtuelle Unternehmen, Franchising, Just in Time in sozialwissenschaftlicher und juristischer Sicht, Baden-Baden: Nomos.

Teubner, Gunther (2004b) "Coincidentia oppositorum: Das Recht der Netzwerke jenseits von Vertrag und Organisation," in M. Amstutz, ed., Die vernetzte Wirtschaft: Netzwerke als Rechtsproblem, Zürich: Schulthess, 11-42. 
Teubner, Gunther (2013) "Exogene Selbstbindung: Die Konstitutionalisierung von Gründungsparadoxien gesellschaftlicher Teilsysteme." Paper presented at Paradoxien der Verfassung, Internationales Workshop, Reggio Emilia, 31 May - 1 June 2013.

Thornhill, Chris (2013) "A Sociology of Constituent Power: The Political Code of Transnational Societal Constitutions." 20 Indiana Journal of Global Legal Studies 551-603.

Varela, Francisco J. (1992) "Whence Perceptual Meaning? A Cartography of Current Ideas," in F. Varela \& J.P. Dupuy, eds., Understanding Origins: Contemporary Views on the Origin of Life, Mind and Society, Dordrecht: Kluwer Academic Publishers, 235-63.

Vesting, Thomas (2007) Rechtstheorie: Ein Studienbuch, München: Beck.

Weber, Max (1968) Gesammelte Aufsätze zur Wissenschaftslehre, Tübingen: Mohr Siebeck.

Weinberg, Alvin M. (1972) "Science and Trans-Science." 10 Minerva 209-22.

Weitzenboeck, Emily M. (2012) A Legal Framework for Emerging Business Models: Dynamic Networks as Collaborative Contracts, Cheltenham: Edward Elgar Publishing.

Welsch, Wolfgang (1996) Vernunft: Die zeitgenössische Vernunftkritik und das Konzept der transversalen Vernunft, Frankfurt: Suhrkamp Verlag.

Weyer, Johannes (2011) Soziale Netzwerke: Konzepte und Methoden der sozialwissenschaftlichen Netzwerkforschung, München: Oldenbourg Wissenschaftsverlag.

Wieacker, Franz (1967) Privatrechtsgeschichte der Neuzeit unter besonderer Berïcksichtigung der deutschen Entwicklung, Göttingen: Vandenhoeck \& Ruprecht.

Wielsch, Dan (2008) Zugangsregeln: Die Rechtsverfassung der Wissensteilung, Tübingen: Mohr Siebeck.

Wielsch, Dan (2009) "Die epistemische Analyse des Rechts: Von der ökonomischen zur ökologischen Rationalität in der Rechtswissenschaft." 2 Juristenzeitung 67-76.

Wiethölter, Rudolf (1968) Rechtswissenschaft, Frankfurt: Fischer.

Wiethölter, Rudolf (1995) "Zur Argumentation im Recht: Entscheidungsfolgen als Rechtsgründe?," in G. Teubner, ed., Entscheidungsfolgen als Rechtsgründe: Folgenorientiertes Argumentieren in rechtsvergleichender Sicht, Baden-Baden: Nomos, 89-120.

Williamson, Oliver E. (1985) The Economic Institutions of Capitalism: Firms, Markets, Relational Contracting, New York: Free Press.

Williamson, Oliver E. (1991) "Comparative Economic Organization: The Analysis of Discrete Structural Alternatives." 36 Administrative Science Quarterly 269-96.

Zöllner, Wolfgang (1996) "Regelungsspielräume im Schuldvertragsrecht: Bemerkungen zur Grundrechtsanwendung im Privatrecht und zu den sogenannten Ungleichgewichtslagen.” 196 Archiv für die civilistische Praxis 1-36. 